\title{
GENDER STEREOTYPES PRESENTED IN POPULAR CHILDREN'S FAIRY TALES
}

\author{
JOANNA PAWŁOWSKA ${ }^{1}$ \\ ${ }^{1}$ The Maria Grzegorzewska University, Institute of Education, Szczęśliwicka 40, Warsaw, 02-353, \\ Poland, ORCID: 0000-0003-0581-0080,Email: jpsd16@aps.edu.pl
}

ABSTRACT: The article aims to contribute to the discussion on gender stereotypes in stories for children by mapping gender stereotypes in traditional fairy tales. The article presents fairy tales' value in children's education and indicates potential dangers in traditional cultural transmissions, paying special attention to gender stereotypes. A selection of texts was analyzed in terms of their stereotypical gender portrayals. The methodological framework represents an interpretative paradigm in social sciences, using a qualitative method of analysis. The texts were purposely selected, and the most popular fairy tales were chosen: Cinderella, Snow White and Sleeping Beauty, which despite the passing of time, are still popular, widely read and also used in film adaptations. It was shown that in all analyzed fairy tales, there was a stereotypical division of roles according to gender. The article also presents possible ways to counteract gender stereotypes. A limitation of the article is that the analysis is limited to three fairy tales only, but the overarching value raises awareness of gender stereotypes in fairy tales for children.

KEYWORDS: gender, gender stereotyping, fairy tale, childhood literature, education, socialization, critical pedagogy

\section{INTRODUCTION}

fairy tale as a literary genre presenting in a simple and compact form the universal experiences of mankind, including existential problems and their desired 
outcomes (Bettelheim 1996), is an important part of most societies' culture. According to a dictionary of literary terms (Głowiński et al. 2008), "fairy tale" belongs to the basic epic genres of folk literature and means "a small-sized work with a fantastic content, saturated with the wonder of magical beliefs, showing the history of human characters freely crossing the boundaries between the world subjected to realistic motivations and the sphere of operation of supernatural forces.” (p. 61). The fairy tales capture the main elements of the folk worldview: belief in the continuous interference of extraterrestrial forces, an anthropomorphic concept of nature, an unwritten moral code, patterns of social relations and proper behavior (Głowiński et al. 2008). The presence of supernatural, magical and fantastic elements and phenomena is a characteristic feature of the genre in question (Rutka 2012; Tychmanowicz 2018). It is also distinguished by a simple plot (which mainly boils down to the fight between good and evil), uncomplicated characters and an unspecified time and place of the events presented (Bednarska 2017; Garbuzik \& Garbuzik 2018; Tychmanowicz 2018). A rich collection of similar fairy-tale motifs and threads appear in texts from all over the world, reflecting cultures that are distant both in time and space (Bettelheim 1996; Głowiński et al. 2008). The combination of these features makes the universal, rich in intrigue motifs, but at the same time easy in reception, fairy-tale message attractive to every recipient, especially a child (Molicka 2002; Tychmanowicz 2018).

The importance of fairy tales for society and individuals is the subject of interest of representatives of many scientific disciplines, including sociology, psychology and pedagogy (Bednarska 2017). One of the best-known authors analyzing the subject of fairy tales in terms of psychology and pedagogy is Bruno Bettelheim $(1976,1996)$, an Australian-American psychiatrist, whose publications have been groundbreaking on this issue. In his famous publication, The Uses of Enchantment. The Meaning and Importance of Fairy Tales (1976), he analyzed fairy tales from a psychodynamic perspective, presenting their educational and therapeutic significance (Bednarska 2017; Tychmanowicz 2018). This author is considered the pioneer of the field commonly referred to as "fairytale therapy" (Bednarska 2017), i.e. the therapeutic use of fairy tales. In Poland, noteworthy are the analyzes carried out by Stefan Szuman (1928) from 1928, which show the results of research on the influence of a fairy tale on the mental functioning of a child (Bednarska 2017; Tychamanowicz 2018), as well as the highly popular works of psychologist Maria Molicka, published from the late twentieth century, in which she writes about fairy tale therapy (Bednarska 2017; Tychmanowicz 2018).

\section{THE VALUE OF FAIRY TALES IN EDUCATIONAL WORK WITH A CHILD}

According to Bettelheim, "a fairy tale is a primer from which a child learns to read in his own mind, a primer written in the language of images. It is the only language by which we can understand ourselves and others before we mature intellectually" (Bettelheim 1996: 256) and "A fairy tale is something unique and specific, not only among literary forms; it is the only piece of art so completely understandable to a child" (Bettelheim 1996: 35). The attractiveness and accessibility of a fairy tale's message for 
a child is largely to the specific features of the world presented in fairy tales: simplicity, one-dimensionality, clarity, personification, anthropomorphization of phenomena and the presence of magical elements (Bettelheim 1996; Tychmanowicz 2018). The unique nature of fairy-tale characters also contributes to the accessible perception of fairy tales by children - they are expressive (it is immediately clear whether they are representative of good or evil), their age is not precise and their names are either ordinary or replaced with a nickname emphasizing their features or position (e.g. Little Red Riding Hood, prince) (Bettelheim 1996; Zawadzka \& Rawa-Kochanowska 2015; Tychmanowicz 2018). Identification with the main characters may also be helped by the fact that these characters are often presented as the "weakest link", as the youngest, neglected or bullied people, which may match the child's perception of their place in the world (Tychmanowicz 2018). Presenting difficult situations connected to childhood fears in fairy tales has a therapeutic effect because, firstly, it shows the young recipient that he/she is not alone in his/hers problems, and secondly, it shows him/ her how to deal with such situations effectively. By identifying with the protagonist, who through his/her own determination and attitude solves their problems, the reader gains courage and hope in dealing with his/her adversities (Bettelheim 1996; Rutka 2012; Tychmanowicz 2018).

Due to its numerous educational and pedagogical values and accessible form, a fairy tale can and should be used in educational working with children. This genre's advantages in question include supporting and stimulating the child's development on a range of levels: cognitive, emotional, social and moral. In terms of cognitive development, contact with a fairy tale stimulates the processes of attention, perception, thinking, memory and assists the stimulation of language skills (Ratyńska 1982; Tychmanowicz 2018). A fairy tale adjusts to a child's perceptive abilities whose cognitive schemas are not fully developed and develops the ability to compare, analyze, and recognize cause-and-effect sequences (Rutka 2012; Garbuzik \& Garbuzik 2018). It provides the opportunity for that child to increase their knowledge about the world, influencing their concentration and exercises memory function. Fairy tales show correct linguistic patterns, enriches the child's vocabulary and encourages them to formulate their statements. In addition, it stimulates the imagination and creativity of a child and can often serve as an inspiration for that child to undertake their own creative activities, thus shaping their creative attitude (Rutka 2012; Tychmanowicz 2018). The fairy tale is also of great importance in the emotional and social development of a child. It provides rich material, showing possible ways of interpersonal interactions, which assists one's understanding of social relations and the motives of human activities and extends the repertoire of one's own behavior (Ratyńska 1982; Pertler \& Pertler 2012; Tychmanowicz 2018). It enables to experience a wide range of emotions, to name and understand them, and develop empathic and anxiety coping skills. (Garbuzik \& Garbuzik 2018; Tychmanowicz 2018). Expressiveness and one-sidedness in presenting good and evil simplify the orientation in moral principles and the consequences of individual behaviors, which contributes greatly to the moral development of a child (Tychmanowicz 2018). A fairy tale is also of great importance in shaping aesthetic sensitivity of the beauty and form of language (Rutka 2012) and introducing 
a child to a fairy tale is a good preparation for their reception of other literary forms (Muchacka 2014; Tychamnowicz 2018). Fairy tales should also be treated as a significant element of the sphere of cultural heritage - they contain a record of the experiences of previous generations, rich in commonly known symbols and metaphors, the knowledge of which facilitates functioning in a given socio-cultural context (Och 2003; Rutka 2012; Tychmanowicz 2018).

\section{THE THREATS FROM THE FAIRY TALE MESSAGE}

Nevertheless, are there some problems behind all these fairy tale qualities? Some authors who deal with the problem of fairy tales answer this question in the affirmative. For example, Grzelka (2019), analyzing fairy tales in the way they present disability, showed that except for The Happy Prince by Oscar Wilde, all the fairy tales she analyzed (The Twelve Brothers, Our Lady's Child, Cinderella, Rapunzel, The Frog King, The Three Feathers, The Girl Without Hands by Grimms, The Little Mermaid, Thumbelina, The Brave Tin Soldier by Andersen, Ricky of the Tuft, Little Thumb by Perrault, The Happy Prince by Wilde, Beauty and the Beast by de Beaumont and Crazy Pietro by Straparola) showed disability as a trait that exposes that person to abuse, ridicule and other negative experiences. According to the author of the analysis mentioned above, these fairy tales reflect the social reality in which, when a happy ending comes, it is associated with the transformation of the disabled person, and not the environment in which the person functions. Most of the transformation into a fully fit person results from prayer and/or good deeds, which may indicate the association of disability with evil and sinful deeds. Even in stories that emphasize the importance of what is "inside" over appearance (for example, Beauty and the Beast), there is a message that by transforming ugly characters into handsome men at the end of the story, it shows that appearance does matter after all (Grzelka 2019).

Some authors also note the limitations of a fairy tale message by presenting motives of cruelty (Zawadzka \& Rawa-Kochanowska 2015) and strengthening attitudes of conformism, obedience and trust towards authority (Czerepaniak-Walczak 2003). Tychmanowicz (2018) strongly refutes the accusations about the appearance of brutal motifs in fairy tales. It turns out that, firstly, the impact of cruel content is not as detrimental to a child's mental development as was initially thought (Pertler \& Pertler 2012; Tychmanowicz 2018), and secondly, cruelty is rarely presented directly, e.g. in the form of blood (Pertler \& Pertler 2012; Tychmanowicz 2018). In addition, it is worth noting that, apart from the fairy-tale message, such content is present in our everyday reality, and there is a high risk that, despite our efforts to prevent this, the child will come across them in their daily activities. It must be considered whether reading fairy tales together with a child is a suitable space to discuss such cruel, brutal motives and to accept them as part of everyday life. Regarding the acceptance of conformist attitudes in fairy tales (Tychmanowicz 2018). Points out that there are also numerous examples in fairy tales of characters who show courage and independence in action. Here, however, the question arises, is this the accurate behavior to evaluate conformism to power/authority? It seems that the phenomenon of conformism is in itself nei- 
ther good nor bad; the situation to which the individual decides to adapt should be analyzed with greater weight.

\section{GENDER STEREOTYPES PRESENTED IN FAIRY TALES}

Another objection to fairy tales is the stereotypical depiction of female and male characters in them, and it is this issue that will be given special attention in this work. Despite raising this issue in Polish (e.g. Slany 2011; Lasoń-Kochańska 2012; Śmiałowicz 2013) and foreign (e.g. Peterson \& Lach 1990; Haase 2004; Kuykendal \& Sturm 2007; El Shaban 2017) publications, there are still misunderstandings and rejections about the harmfulness of such messages in fairy tales, and the efforts made to achieve gender equality do not seem to bring satisfactory results.

Śmiałowicz (2013) in her publication Fairy tales and asymmetrical gender relationships reproduction indicates the relationship between the patterns of "femininity" and "masculinity" shown in the cultural message and the problem of unequal treatment on the basis of gender. At the beginning of her work, the author provides examples showing that despite the legal prohibition of discrimination in Poland, equality in Polish society is still a matter of wishes, not facts. She cites, inter alia, studies that show that women, despite better cooperation with each other in same-sex groups than in groups with men (Carli 2006). When asked about the gender of people with whom they prefer to work, they choose to cooperate with men. According to other studies (Budrowska, Duch-Krzysztof \& Titkow 2003), both women and men are equally reluctant to place women in managerial positions, with men, who constitute the majority of people holding prestigious positions, forming subgroups and coalitions, serving their interests, while women, when asked about female solidarity, prefer to answer this question with minimal commentary. The research conducted by Pawłowska (2019) among students and academic staff of a pedagogical university showed that discrimination on the basis of gender, manifested, inter alia, in the reluctance to fill women in managerial positions, is still a current phenomenon.

According to Śmiałowicz (2013), the tendency of men to support each other and the lack of solidarity among women, while at the same time striving for men's favor, are culturally constructed features internalized during socialization. The material that exemplifies this gender issue is chosen by the fairy tale as a timeless genre, the threads of which are common to most cultures, and the symbolic motifs are internalized from an early age, shaping the recipient's identity (Śmiałowicz 2013). Claims that:

(...) certain content of selected fairy tales and the lessons derived from them do not correspond to contemporary social reality, because they are the result of 19 th and 20th century modifications, introduced at that time in order to raise children with the sense of morality at the time. Thus, the patterns instilled in girls prepare them to perform roles considered appropriate in a patriarchal society, but unjustified in contemporary democratic societies, whose basic feature is equal opportunities and equality. (p. 342)

Tychmanowicz (2018: 107) refutes this argument by referring to the position of the 
authors who "notice that despite the fact that the plot is embedded in a certain order of social norms and rules, the characters of fairy tales are often brave girls" (Pertler \& Pertler 2012; Zawadzka \& Rawa-Kochanowska 2015).

These counter-arguments do not undermine Śmiałowicz's thesis. Firstly, at the very beginning of Śmiałowicz's statement, it is noted that it refers only to “certain content of selected fairy tales". Secondly, the mere presence of brave girls in some stories does not dispel the harmful impact of presenting gender stereotypes in other fairy tales, especially since the latter are still the most popular, the motives of which are also willingly used in other cultural messages. It is widely known that the traditional canon of European fairy tales, which has survived to this day, reflects and reproduces the systems' patriarchal values from the times in which these fairy tales were created (Kuykendal \& Sturm 2007). Based on a number of studies (Key 1971; Weitzman et al. 1972; Lach \& Peterson 1990; Demarest \& Kortenhaus 1993) that discovered patterns of male dominance and female submission in fairy tales, researchers concluded that repeated exposure to gender stereotyping can have a detrimental effect on children's self-esteem, as well as on the perception of their own abilities and potential (Peterson \& Lach 1990; Kuykendal \& Sturn 2007). Since fairy tales can significantly impact the formation of gender identity, it is important to look at the message portrayed in them.

The most famous fairy tales were propagated as the desired model of a woman: weak, subject, dependent, passive, enslaved, silent and self-sacrificing, while the men they portray are powerful, active and dominant (Kuykendal \& Sturm 2007; Slany 2011; Śmiałowicz 2013). The popular fairy tales about Sleeping Beauty and Cinderella lead the way in this presentation of women. In both of these stories, innocence and goodness are equated with beauty, which, as a trait worthy of envy, ultimately guarantees the success of the person who possesses it (Śmiałowicz 2013). For example: bad, ugly sisters lose to the beautiful and good Cinderella in a fight for the favor of a powerful man. The reward here is, therefore, the love, attention and recognition of the man, as well as the possibility of getting married as the primary goal of every woman's actions. A handsome, young man is presented in fairy tales as "a trophy, a prize, the embodiment of the highest value instilled in women from childhood, which causes them to copy behaviors resulting from cultural oppression without thinking” (Slany 2011: 277).

However, in order for Cinderella to be noticed by the prince at all, she must undergo a metamorphosis, which is a literal metamorphosis, because it is only a physical, bodily transformation (Slany 2011). The protagonist "dressed in her gender" by fairytale stylists, symbolized by high heels, dress or makeup, comes down to the role of a "mysterious seductress" sending, during the ball, signs perceived by society as a lure to be "acquired" and "owned" (Slany 2011). Thanks to all these endeavors, a woman becomes noteworthy by the subjective male figure, while acting on the male senses only through her appearance, her "body", she becomes objectified. (Slany 2011).

The spells of good fairies uttered to neutralize the evil spell cast on the Sleeping Beauty tell a lot about the desired model of femininity in fairy tales (Śmiałowicz 2013: 347).

"The youngest ordained that she should be the most beautiful person in the world; the next, that she should have the temper of an angel; the third, that she should do 
everything with wonderful grace; the fourth, that she should dance to perfection; the fifth, that she should sing like a nightingale; and the sixth, that she should play every kind of music with the utmost skill (Perrault)".

In fairy tales, we can also find other models of female characters who are powerful, talkative, enterprising, but these traits are also accompanied by that character being evil, ugly and/or stupid (Evans 1996; Kuykendal \& Sturm 2007). The exception to this rule may be the good fairy who helps Cinderella, but she does not appear in all versions of this fairy tale, and importantly, she is not fully human (Mendelson 1997; Kuykendal \& Sturm 2007).

So far, the models of femininity presented in traditional fairy tales have been presented. It is also worth looking at the proposed patterns of relationships built by women. When analyzing the fairy tales mentioned so far, one cannot help but get the impression that in most of them, relationships between women are based on jealousy and competition. In the fairy tale Cinderella, the main character competes for the favor of the prince with her sisters who are jealous of her beauty. She does not get any support from other women, on the contrary - the stepmother is also not on Cinderella's side; she mistreats her, supporting her own daughters in every situation Bettelheim (1996: 368) interprets Cinderella's tale as “a story about jealousy and fights related to rivalry between siblings and about the heroine's victory over her persecuting and degrading sisters". Bettelheim adds that there are fairy tales in which boys experience similar events, but as Śmiałowicz (2013) rightly notes, "it does not change the fact that the most popular fairy tale, if read it literally, is about girls' rivalry” (p. 343), and also that the prize in this competition is the favors of a powerful man.

A similar image of the difficult girl-stepmother / mother relationship can be seen in the popular fairy tale "Snow White". As Bettelheim notes: "in the most widespread version of the fairy tale, a jealous adult woman is Snow White's stepmother, not her mother, about a person whose love creates a competitive situation between two female characters (i.e. about Snow White's father and her stepmother's husband) is not mentioned at all. So, the fact that the Oedipal problems are the source of the conflict in the story is up to our imagination" (Bettelheim 1996: 314). Based on this fairy tale, one can see that the mother will compete with her rival for the favor of men (Śmiałowicz 2013). Since the figure of a man is obliterated in Snow White, beauty becomes the battlefield, as evidenced by the well-known phrase "Mirror mirror tell me, who is the most beautiful in the world?" (Śmiałowicz 2013). Ultimately, the girl wins this competition as a young and good person, in contrast to her jealous, older stepmother, who is even ready to go so far as to kill her younger rival (Śmiałowicz 2013).

No better picture of female relationships emerges from another popular fairy tale - Sleeping Beauty. In the most popular version of this fairy tale, an evil fairy who felt rejected by the lack of an invitation to the princess' baptism, decides to cast a killing spell on her in the act of revenge, which will start working when the princess pricks herself with a spindle. Although the kingdom would be ordered to get rid of all the spindles, there is an old spinner in the castle, which, unaware of the danger, shows the young girl this item. In this case, the old woman made a mistake and refused to do evil deliberately. Nevertheless, in Charles Perrault's version, other women are the cause of 
the young protagonist's suffering, and they are presented either as chimerical, offensive like an evil fairy or simply stupid or unaware of the situation, like an old spinner (Śmiałowicz 2013).

Based on the review of these fairy tales, a portrait of the mother/stepmother/queen/ fairy emerges as destructive and vindictive, striving to destroy her younger rival (Slany 2011). In his analysis, Bettelheim combined this type of rivalry with jealousy for a man - a leader who wields power in a patriarchal order (Slany 2011). The older women guardian perceives the young, adolescent girl character as another rival in the race for male recognition and the most valuable award - marriage (Slany 2011). Women do not fight each other directly, their weapon in competition is most often manipulation or intrigue, and so "older women order to poison, kill, lock in a tower or put them to sleep one hundred years younger ones" (Slany 2011: 284).

As one can see, fairy tales in which the main characters are women, rarely have friendly, cordial, cooperative and supportive relations with other women. However, it is not difficult to mention examples of fairy tales full of such relationships between men, e.g. fairy tales about wise brothers, Peter Pan, Arthurian legends (Śmiałowicz 2013), or Tolkien's trilogies such as The Lord of the Rings or The Hobbit. The fact that cordial relations in the Polish cultural message are reserved mainly for boys, while in the case of girls, they are neglected, also shows that there is no equivalent for the word "brotherhood" in Polish (Śmiałowicz 2013). Currently, however, it can be noticed that the Polish term "siostrzeństwo” [,sisterhood”] despite not appearing in Polish language dictionaries, began to be used in feminist discourse both in the press and in scientific publications, as evidenced by e.g publication by K. Sikorska (2019) "Siostrzeństwo i jego dyskursywne użycia” [,Sisterhood and its Discursive Application”].

The patterns of femininity and masculinity presented so far, and the models of relationships built by women and men are only some examples of gender stereotypes presented in traditional fairy tales, included here only to highlight the problem. A broad study of this issue in a similar convention in Poland can be found, for example, in the publications of Slany (2011), Lasoń-Kochańska (2012), Śmiałowicz (2013), while in the English-language literature in the publications of Lieberman (1972), Yolen (1977), Rowe (1979), Zipes (1995; 2006; 2007; 2012, 2014), Bacchilega (1997), Haase (2004), England, Descartes, and Collier-Meek (2011), Heerspink (2012), Nanda (2014), Samuel (2015), Shaban (2017), Meland (2020), Zabrzewska (2019) in the article Gender in Literature for Children: Feminist 'Body, Voice, and Story' Methodology lists the latest studies on children's and youth literature based on the feminist theory: Curry (2013), Kokkola (2013), Ratelle (2014), Flanagan (2014), Jaques (2015), Feuerstein, Nolte-Odhiambo (2017), Trites (2018).

\section{HOW TO COUNTER GENDER STEREOTYPES IN FAIRY TALES?}

What measures can be taken to prevent harmful gender stereotypes from spreading throughout fairy tales? One of the proposals was presented by the Taber school authorities in Barcelona, establishing a commission whose aim was to find sexist content in the collections of the school library (Flood 2019). As a result of the commission's 
activities, about 200 titles (including Sleeping Beauty, Little Red Riding Hood or The legend of Saint George) were removed, which accounts for $30 \%$ of books for children in these collections. The decision to remove these items was argued because of the presence of strong stereotypes and the lack of pedagogical value (Flood 2019). While such radical actions may evoke objections at first, it should be noted that eliminating the items concerned books addressed to preschool children, i.e. in the period in which gender identity is formed. Only primary school students have a greater ability to think critically compared to preschool children, which also translates into the possibility of greater reflection on the content presented in the literature. So, it seems that the solution in this case, instead of completely eliminating some items from the library's collection, would be to address these books to an older audience. The drastic, complete liquidation of the items belonging to the canon of fairy tales may be harmful, because it deprives us of valuable material for working on gender stereotypes, which are present not only in fairy tales, but also in the "non-fairy-tale" reality that surrounds us (e.g. in animated cartoons, movies, commercials). Many cultural messages, including film scenarios, are based on patterns typical of fairy tales, which result from the influence of the centuries-old patriarchal order. Changes in the perception of what is "feminine" and "masculine" will not be achieved by an attempt to "erase" the existing patterns that have been functioning for hundreds of years from the "reading list". These should be seen as part of our history, and fairy tales depicting gender stereotypes can be seen as valuable material for preventing duplication of gender stereotypes.

In the publication by Śmiałowicz (2013: 355) we can read that “(...) if you believe words that the meaning of a fairy tale is given by the person telling it, you only need to re-read them, so as not to repeat harmful stereotypes. It is the interpretations of fairy tales and how they have been adapted to perform an educational function that is discriminatory, not fairy tales or their message, which is universal not because it does not change, on the contrary - precisely because it is subject to change". On the basis of these words, it can be concluded that it is the person who acquaints the young reader with the fairy tale, and therefore most often the teacher, parent or guardian, that is the key to the proper reception of the fairy tale. Therefore, it is very important that each person introducing a child into the world of fairy tales is aware of the potential dangers hidden in the fairy tale message and that he/she knows how to counteract these potential dangers. Teacher's awareness can be raised during the academic stage of teaching studies by sensitizing to gender stereotypes in cultural transmission, as presented by Odrowąż-Coates (2016) in her article „Lessons on social justice: a pedagogical reflection on the educational message of The Boxtrolls”. Moreover, it seems important to familiarize guides of the world of fairy tales with publications on gender stereotypes both in the fairy tale message and in other cultural messages. In addition to the previously presented publications on the subject in the context of fairy tales, interesting texts to read may be the works of such authors as: Bell (1995), Cuomo (1995), Wells (1998), Sun and Scharrer (2004), Brode (2005), Kirkorian, Wartella \& Anderson (2008), Schiappa (2008), Storey (2010), Höijer (2011). Suggestions for working with fairy tales showing gender stereotypes include replacing the names of characters with names of the opposite sex in traditional stories or using neutral terms (such as "hen") 
for characters so that children can imagine the gender of the character themselves (Odrowąż-Coates 2015). The teacher may also encourage children to try to create alternative versions of events or the ending of a story from the perspective of real-life (Slany 2011). In addition to changing the names of the characters with names of the opposite sex, other elements of the fairy tale can be modified, e.g. the character traits of individual characters, as proposed by (Śmiałowicz 2013): "It would be enough for Cinderella's sisters to be as beautiful and good as she, and their only offense was the lack of empathy for the youngest sister and this behavior would be punished at the end of the fairy tale" (p. 355). Finally, a solution may be to create new fairy-tale propositions yourself.

As these solutions may raise doubts and concerns about destroying the original, traditional versions of well-known stories, it should be remembered that although the European canon of fairy tales is called "original fairy tales", there is no such thing as "true, authentic version of a fairy tale" (Parsons 2004; Kuykendal \& Sturm 2007). A fairy tale, like the culture it is a product of, evolves (Śmiałowicz 2013), confirmation of which can be found in the words of Molicka (2011): "You cannot talk about authentic, primal fairy tales - they constantly evolved along with the development of the community that created them" (p. 177). Sometimes there is also a misconception that the fairy tale grows out of oral tradition, folklore, but in the following words of Molicka (2011: 177-179) we learn that: “(...) the fairy tales consisted of local legends, beliefs, stories repeated from mouth to mouth, and on the other hand, literary works. Today it is already known that original folklore fairy tales do not exist, as they were usually inspired by literary works, which in turn were created on the basis of traditional oral communication, therefore the emerging and known literary and folk works of this type had a mutual, reciprocal influence" (p. 178). Therefore, the proposals described in the previous paragraph should not raise objections from the supporters of "traditional fairy tales".

Other examples of preventive actions against the reproduction of stereotypical femininity and masculinity patterns include selecting texts that do not contain gender stereotypes (Odrowąż-Coates 2015). In terms of fairy tales, an interesting proposition may be The Tales of Beedle the Bard by J. K. Rowling (2008), about which the author herself writes in the introduction as follows: "Another notable difference between these fables and their Muggle counterparts is that Beedle's witches are much more active in seeking their fortunes than our fairy-tale heroines. Asha, Altheda, Amata and Babbitty Rabbitty are all witches who take their fate into their own hands, rather than taking a prolonged nap or waiting for someone to return a lost shoe. The exception to this rule - the unnamed maiden of “The Introduction xiii Warlock's Hairy Heart” - acts more like our idea of a storybook princess. However, there is no „happily ever after" at the end of her tale." (p. 12). On the Polish "literary scene”, there are also many examples of this, including the works collected in the volume Polish Fairy Tale, which with their origins go back to the Middle Ages, being one of the oldest and most valuable monuments of Polish literature (Slany 2011). They present the realities of rural life and the humorous adventures of peasants who strive for happiness, trying to deceive their destiny through activity and cunning (Slany 2011). The devil's figure is 
an antagonist towards the peasants and their aspirations, who is the embodiment of all evil. Outsmarting him and fate is the main goal of the heroes of Polish fairy tales, and despite the fact that in the peasant hierarchy, a woman is placed lower than a man, it is a rural woman who is go-getting, clever, enterprising, witty and resolute, the devil is most afraid (Slany 2011). Thanks to the protagonists' colourful personalities, Polish fairy tales are an interesting alternative to traditional fairy tales in presenting patterns of social and cultural gender.

In order not to be limited only to fairy tales, children can be offered to get acquainted with other literary, musical, theatrical and film forms free from these stereotypes. An interesting alternative to traditional fairy tales can be, for example, the stories by the famous writer, screenwriter and publicist Roald Dahl. In addition to his most famous books for children, such as Charlie and the Chocolate Factory or The BFG, he is also the author of Revolting Rhymes, Matilda, The Witches, Fantastic Mr Fox, The Enormous Crocodile. On Polish ground, for example, you can find works by Andrzej Sapkowski, in which the "warrior", "fighter" type of woman is promoted, in opposition to the models of femininity presented in traditional fairy tales (Slany 2011). Among the cinematographic proposals, the American animated film Brave directed by Mark Andrews deserves attention. The main character, Princess Merida, despite objections from some people around her, has been interested in archery and horse riding from an early age, showing an aversion to court etiquette. It is a production that is not about love for the prince, and the happy ending is not synonymous with the upcoming marriage, which skillfully breaks stereotypes about women's aspirations.

That being said, it should be noted that "subversive gender representations are not about making a one hundred and eighty degree mechanical turn” (Zabrzewska 2019: 13). So, the goal is not to present all male characters as passive, submissive, dependent, emotional or silent, and female characters as active, powerful, dominant, rational or talkative. The presented treatments are intended to show that each person can choose the appropriate model of behavior depending on the circumstances, their predispositions and preferences, and not due to belonging to a given gender (Zabrzewska 2019).

\section{SUMMARY}

According to the presented considerations, a fairy tale is an invaluable tool in children's education due to its numerous advantages. However, it is not a tool without its drawbacks; many authors point out some dangers resulting from the message flowing from the fairy tale. One of the charges against fairy tales raised by researchers is the stereotypical representation of male and female characters. Based on studies (Key 1971; Weitzman et al. 1972; Lach \& Peterson 1990; Demarest \& Kortenhaus 1993) that discovered patterns of male dominance and female submission in fairy tales, researchers concluded that repeated exposure to stereotypical gender representation can have a detrimental effect on children's self-esteem as well as their perception of their own abilities and potential (Peterson \& Lach 1990; Kuykendal \& Sturn 2007). Therefore, it becomes advisable to undertake activities that could counteract the 
harmful influence of the stereotypical representation of gender in the fairy-tale message. Such actions, which have been described in more detail in the article, include: replacing the names of characters with names of the opposite sex in traditional stories or using neutral terms for the characters so that children can imagine the gender of the character themselves (Odrowąż-Coates 2015); encouraging children to try to create alternative versions of events or the ending of a story from the perspective of real-life (Slany 2011); modifying other elements of the fairy tale, e.g. the character traits of individual characters (Śmiałowicz 2013); independent creation of new fairy-tale proposals; selecting texts that do not contain gender stereotypes (OdrowążCoates 2015); introducing children to other literary, musical, theatrical and film forms free from the stereotypes discussed.

The examples listed here are just a handful of suggestions that can counteract the harmful gender stereotypes presented in fairy tales. However, in order for all these preventive actions to take place and bring the desired result, it must be kept in mind that it is necessary, in the first place, to raise awareness of the issues discussed among the people who have the greatest impact on shaping the attitudes of the youngest recipients of fairy tales. These people include adults who are important to the child, i.e. teachers, parents, guardians introducing children to the world of fairy tales and explaining the surrounding reality to the child. Suppose these people themselves are not sensitive to the issues of gender equality. In that case, they will not see any legitimacy in applying these preventive measures against the harmful effects of gender stereotypes. Therefore, it is important to undertake all actions aimed at raising awareness of the problem.

FUNDING: This research received no external funding.

CONFLICT OF INTEREST: The author declares no conflict of interest.

\section{REFERENCES}

Bacchilega, Cristina. 1997. Postmodern Fairy Tales: Gender and Narrative Strategies. Philadelphia, PA: University of Pensylwania Press.

Bednarska, Gabriela. 2017. "Praca z bajką w procesie wychowania dziecka w wieku przedszkolnym i wczesnoszkolnym: zagadnienia terminologiczne i metodyczne.” Annales Universitatis Paedagogicae Cracoviensis. Studia Psychologica 10(1): $108-130$.

Bell, Elizabeth. 1995. "Somatexts at the Disney shop: Constructing the pentimentos of women's animated bodies.” Pp. 107-124 in From mouse to mermaid: The politics of film, gender, and culture. Bloomington: Indiana University Press.

Bettelheim, Bruno. 1976. The Uses of Enchantment: The Meaning and Importance of Fairy Tales. New York: Vintage Books.

Bettelheim, Bruno. 1996. Cudowne i pożyteczne: o znaczeniach i wartościach baśni. Translated by Danek Danuta. Warszawa: Wydawnictwo W.A.B. 
Brode, Douglas. 2005. Multiculturalism and the mouse: Race and sex in Disney entertainment. Austin: University of Texas Press.

Budrowska, Bogusława, Danuta Duch, \& Anna Titkow. 2003. Szklany sufit: bariery $i$ ograniczenia karier polskich kobiet. Warszawa: ISP.

Carli, Linda L. 2006. "Gender issues in workplace groups: Effects of gender and communication style on social influence." Pp. 69-83 in Gender and communication at work, edited by M. Barrett, M. Davidson. Aldershot, Hants, England, Burlington, VT: Ashgate Pub.

Connor, David J. 2009. "Creating cartoons as representation: Visual narratives of college students with learning disabilities." Educational Media International 46(3):185-205.

Cuomo, Chris. 1995. “Spinsters in sensible shoes.” Pp. 212-223 in From mouse to mermaid: the politics of film, gender, and culture. Bloomington: Indiana University Press.

Curry, Alice. 2013. Environmental Crisis in Young Adult Fiction: A Poetics of Earth. New York, NY: Palgrave Macmillan.

Czerepaniak-Walczak, Maria. 2003. "Pułapki izonomii rozwojowej w baśniowym świecie. (O potrzebie krytycznej refleksji nad bajkami jako środkiem wychowania).” Pp. 10-24 in Barwy świata baśni, edited by: U. Chęcińska. Szczecin: Wydawnictwo Uniwersytetu Szczecińskiego.

El Shaban, Abir. 2017. "Gender stereotypes in fantasy fairy tales: Cinderella." Arab World English Journal for Translation \& Literary Studies 1(2):123-137.

England, Dawn Elizabeth, Lara Descartes, \& Melissa A. Collier-Meek. 2011. "Gender role portrayal and the Disney princesses." Sex roles 64(7): 555-567.

Evans, Karen. S. 1996. "A Closer Look at Literature Discussion Groups: The Influence of Gender on Student Response and Discourse.” New Advocate 9(3): 183-96.

Feuerstein, Anna \& Carmen Nolte-Odhiambo. 2017. Childhood and Pethood in Literature and Culture. New Perspectives in Childhood Studies and Animal Studies. New York, NY: Routledge.

Flanagan, Victoria. 2014. Technology and Identity in Young Adult Fiction: The Posthuman Subject. London, UK: Palgrave Macmillan.

Flood, Alison. 2019. “Barcelona school removes 200 sexist children's books.” The Guardian. Retrieved September 20, 2020 (https://www.theguardian.com/books/2019/ apr/18/barcelona-school-removes).

Garbuzik, Paweł \& Katarzyna Garbuzik. 2018. “O znaczeniu i wartości baśni w pracy pedagogicznej”. PEDAGOGIKA 27(1): 129-137.

Głowiński, Michał, Teresa Kostkiewiczowa, Aleksandra Okopień-Sławińska, \& Janusz Sławiński. 2008. Słownik terminów literacki. Wrocław: Zakład Narodowy im. Ossolińskich.

Grzelka, Michalina. 2019. "Representation of Disability in Fairy Tales from the Perspective of the Social Model of Disability. A Case Study of Fairy Tales by Jacob and Wilhelm Grimm, Hans Christian Andersen, Oscar Wilde, Charles Perrault, Giovanni Francesco Straparola, and Jeanne-Marie Leprince de Beaumont." International Journal of Pedagogy Innovation and New Technologies 6(1): 107-114. 
Haase, Donald. 2004. Fairy Tales and Feminism: New Approaches. Detroit, MI: Wayne State University Press.

Heerspink, Dawn. 2012. “No Man's Land: Fairy Tales, Gender, Socialization, Satire, and Trauma During the First and Second World Wars.” Grand Valley Journal of History 1(1): 1-29.

Höijer, Birgitta. 2011. "Social representations theory: a new theory for media research.” Nordicom Review 3(2): 3-16.

Jaques, Zoe. 2015. Children's Literature and the Posthuman: Animal, Environment, Cyborg. New York, NY: Routledge.

Key, Mary R. 1971. “The role of male and female in children's books: Dispelling all doubt.” Pp. 55-70 in Women: Dependent or independent variable?, edited by $\mathrm{R}$. Unger \& F. Denmark. New York: Psychological Dimensions.

Kirkorian, Heather L., Ellen A. Wartella, \& Daniel R. Anderson. 2008. "Media and Young Children's Learning”. The Future of Children 18(1): 39-61

Kokkola, Lydia. 2013. Fictions of Adolescent Carnality: Sexy sinners and delinquent deviants. Amsterdam \& Philadelphia: John Benjamins Publishing Company.

Kortenhaus, Carole M. \& Jack Demarest. 1993. “Gender role stereotyping in children's literature: An update.” Sex roles 28(3-4): 219-232.

Kuykendal, Leslee F. \& Brian W. Sturm. 2007. "We said feminist fairy tales, not fractured fairy tales!" Children \& Libraries: The Journal of the Association for Library Service to Children 5(3): 38-41.

Lasoń-Kochańska, Grażyna. 2012. Gender w literaturze dla dzieci i młodzieży. Wzorce płciowe i kobiecy repertuar topiczny. Słupsk: Wydawnictwo Naukowe Akademii Pomorskiej w Słupsku.

Lieberman, Marcia R. 1972. "Some Day My Prince Will Come: Female Acculturation through the Fairy Tale." College English 34(3): 383-395.

Meland, Aud Torill. 2020. "Challenging gender stereotypes through a transformation of a fairy tale." European Early Childhood Education Research Journal 28(6): 1-12.

Mendelson, Michael. 1997. "Forever Acting Alone: The Absence of Female Collaboration in Grimms' Fairy Tales." Children's Literature in Education 28(3): 111-25.

Molicka, Maria. 2002. Bajkoterapia: o lękach dzieci i nowej metodzie terapii. Poznań: Wydawnictwo Media Rodzina.

Molicka, Maria. 2011. Biblioterapia i bajkoterapia: rola literatury w procesie zmiany rozumienia świata społecznego i siebie. Poznań: Wydawnictwo Media Rodzina.

Muchacka, Bożena. 2014. “Zabawa w poznawczym rozwoju dziecka.” Pedagogika Przedszkolna i Wczesnoszkolna 1(3): 7-18.

Nanda, Silima. 2014. “The Portrayal of Women in the Fairy Tales.” Valley International Journals 1(4): 246-250.

Och, Katarzyna. 2003. “Rola bajki w edukacji.” Wychowanie w Przedszkolu 10: 594-597.

Odrowąż-Coates, Anna. 2015. “Is gender neutrality a post-human phenomenon? The concept of 'gender neutral' in Swedish education." Journal of Gender and Power 3(1): 113-133.

Odrowąż-Coates, Anna. 2016. "Lessons on social justice: a pedagogical reflection on the educational message of The Boxtrolls.” Education as Change 20(2): 67-85. 
Parsons, Linda T. 2004. "Ella evolving: Cinderella stories and the construction of gender-appropriate behavior." Children's literature in education 35(2): 135-154.

Pawłowska, Joanna. 2019. “Równość szans pracowników i pracowniczek akademickich Akademii Pedagogiki Specjalnej im. Marii Grzegorzewskiej ze względu na płeć w opinii studentów i studentek oraz nauczycieli i nauczycielek akademickich.” Edukacja - Technika - Informatyka 1(special issue): 80-85.

Perrault, Charles. The Sleeping Beauty in the Wood. Retrieved September 20, 2020 (https://www.pitt.edu/ dash/perrault01.html).

Pertler, Cordula \& Reinhold Pertler. 2012. Baśnie w przedszkolu: bajkoterapia $w$ pracy $z$ dziećmi. Kielce: Wydawnictwo JEDNOŚĆ.

Peterson, Sharyl B. \& Mary A. Lach. 1990. “Gender stereotypes in children's books: Their prevalence and influence on cognitive and affective development.” Gender and education 2(2): 185-197.

Ratelle, Amy. 2014. Animality and Children's Literature and Film. London, UK: Palgrave Macmillan.

Ratyńska, Hanna. 1982. "Rola książki i czasopisma w wychowaniu przedszkolnym.” Pp. XX-XX in Kultura literacka $w$ przedszkolu, edited by S. Frycie \& I. Kaniowska-Lewańska. Warszawa: WSiP.

Resene, Michelle. 2017. “From Evil Queen to Disabled Teen: Frozen Introduces Disney's First Disabled Princess.” Disability Studies Quarterly 37(2): 65-83 .

Rowe, Karen E. 1979. “Feminism and fairy tales.” Women's Studies: An Interdisciplinary Journal 6(3): 237-257.

Rowling, Joanne K. 2008. The tales of Beedle the Bard. London: Children's High Level Group.

Rutka, Wioletta. 2012. “Wartości baśni w pracy z dziećmi przedszkolnymi.” Edukacja Elementarna $w$ Teorii i Praktyce 24(2): 27-44.

Samuel, Lawrence R. 2015. American fatherhood: A cultural history. London: Rowman \& Littlefield.

Schiappa, Edward. 2008. Beyond representational correctness: Rethinking criticism of popular media. Albany, NY: State University of New York Press.

Sikorska, Karolina. 2019. „Siostrzeństwo i jego dyskursywne użycia.” Acta Universitatis Lodziensis. Folia Sociologica 70: 39-58.

Slany, Krystyna. 2011. "Płeć kulturowa w tradycyjnych zbiorach baśniowych najpopularniejszych na gruncie polskim.” Pp. 273-297 in Kalejdoskop genderowy. W drodze do poznania płci społeczno-kulturowej w Polsce, edited by: K. Slany, B. Kowalska, \& M. Ślusarczyk. Kraków: Wydawnictwo Uniwersytetu Jagiellońskiego.

Śmiałowicz, Katarzyna. 2013. “Baśnie i odtwarzanie asymetrycznych relacji płciowych.” Studia Edukacyjne 27: 337-357.

Storey, John. 2010. Culture and Power in Cultural Studies: the politics of signification. Edinburgh: Edinburgh University Press.

Sun, Chyng Feng \& Erica Scharrer. 2004. “Staying true to Disney: College students' resistance to criticism of The Little Mermaid." The Communication Review 7(1): $35-55$.

Szuman, Stefan. 1928. "Wpływ bajki na psychikę dziecka.” Szkoła Powszechna 1-2: 
173-207.

Trites, Roberta S. 2018. Twenty-first-century Feminisms in Children's and Adolescent Literature. Jackson, Missisipi: University Press of Mississippi.

Tychmanowicz, Anna. 2018. "Dawno, dawno temu... O roli baśni w wychowaniu i edukacji.” Annales Universitatis Mariae Curie-Skłodowska, sectio J-Paedagogia-Psychologia 31(3): 101-111.

Wagner, Wolfgang, Robert Farr, Sandra Jovchelovitch, Fabio Lorenzi-Cioldi, Ivana Marková, Gerard Duveen, \& Diana Rose. 1999. “Theory and method of social representations." Asian Journal on Social Psychology 2(1): 95-125.

Weitzman, Lenore J., Deborah Eifler, Elizabeth Hokada, \& Catherine Ross. 1972. “Sexrole socialization in picture books for preschool children.” American Journal of Sociology 77(6): 1125-1150.

Wells, Paul. 1998. Understanding Animation. London: Routledge.

Yolen, Jane. 1997. “America's Cinderella.” Children's Literature in Education 8(1): 21-29.

Zabrzewska, Adrianna. 2019. “Gender w literaturze dla dzieci. Feministyczna metodologia: Ciało, Głos, Opowieść.” AVANT 11(3): 1-18.

Zawadzka, Ewa \& Anita Rawa-Kochanowska. 2015. Magiczny świat baśni i bajek: metafory $i$ symbole $w$ procesie wspomagania dziecka $w$ rozwoju. Warszawa: Difin.

Zipes, Jack. 1995. “Breaking the Disney spell.” Pp. 21-42 in From mouse to mermaid: The politics of film, gender, and culture. Bloomington: Indiana University Press.

Zipes, Jack. 2006. Why Fairy Tales Stick: The Evolution and Relevance of a Genre. New York: Routledge.

Zipes, Jack. 2007. When Dreams Came True: Classical Fairy Tales and Their Tradition. New York: Routledge.

Zipes, Jack. 2012. Fairy Tales and the Art of Subversion: The Classical Genre for Children and the Process of Civilization. New York: Routledge Classics.

Zipes, Jack. 2014. Don't bet on the prince: Contemporary feminist fairy tales in North America and England. New York: Routledge.

\section{BIOGRAPHICAL NOTE}

Joanna Pawłowska, MA in Pedagogy and MA in Psychology, PhD student at the The Maria Grzegorzewska University in Warsaw, Poland. She is interested in inequalities based on gender, gender studies, socialization processes and socio-psychological factors in education.

OPEN ACCESS: This article is distributed under the terms of the Creative Commons Attribution Non-commercial License (CC BY-NC 4.0) which permits any non-commercial use, and reproduction in any medium, provided the original author(s) and source are credited. 